\title{
Percutaneous transluminal angioplasty/stent treatment of totally occlusive iliofemoral artery with limb ischemia: Experience of surgical team
}

\author{
Bacak iskemisi olan iliofemoral total oklüzyonlu hastalarda perkütan translüminal \\ anjiyoplasti/stent tedavisi: Cerrahi Ekibin deneyimi \\ Emin Can Ata ${ }^{1}$ ', Muharrem Şenel ${ }^{2}$ \\ Institution where the research was done: \\ Private Eskişehir Anadolu Hospital, Eskişehir, Turkey \\ Author Affiliations: \\ 'Department of Cardiovascular Surgery, Private Eskişehir Anadolu Hospital, Eskişehir, Turkey \\ ${ }^{2}$ Department of Cardiovascular Surgery, Private Su Hospital, Izmir, Turkey
}

\begin{abstract}
Background: In this study, we present our center's experience on percutaneous transluminal angioplasty/stenting.

Methods: Between January 2015 and March 2017, a total of 40 patients (34 males, 6 females; mean age $64.5 \pm 8.7$ years; range, 49 to 85 years) who were treated in our clinic due to totally occluded iliofemoral artery disease were included. There were 45 legs and 51 targeted vessels. Hybrid procedure was performed to those patients with iliofemoral or femoropopliteal bypass grafts.

Results: A total of 48 target vessels $(94.1 \%)$ were implanted using 55 stents at the initial attempt. Failed three target vessels (5.9\%) were treated by surgical revascularization. There was no procedure-related mortality. Below-knee amputation was performed in one patient after 70 days. Two patients underwent single-finger amputation. Contrast nephropathy occurred in one patient and this patient was treated medically. The mean follow-up was $16.7 \pm 5$ (range, 8 to 29) months. After follow-up, 41 stents were found to be patent without any intervention, and the primary patency rate was $74.5 \%$. Five stent thrombosis patients (12.5\%) were treated at different times.

Conclusion: Our study results suggest that percutaneous transluminal angioplasty/stent treatment may be advisable in patients with significant comorbidities. The lower rates of complication in the stent series strongly suggest that, in experienced hands, percutaneous transluminal angioplasty/stent can offer lower procedural risks than surgical revascularization. Hybrid procedure is likely to be a reasonable choice for previously intervened comorbid patients for limb salvage.
\end{abstract}

Keywords: Claudication; hybrid revascularization; percutaneous transluminal angioplasty/stent; total occlusion.
$\ddot{O Z Z}$

Amaç: $\mathrm{Bu}$ çalışmada, merkezimizin perkütan translüminal anjiyoplasti/stentleme deneyimi sunuldu.

Çalışma planı: Ocak 2015 - Mart 2017 tarihleri arasında iliofemoral total oklüzyon hastalığı nedeniyle kliniğimizde tedavi edilen toplam 40 hasta (34 erkek, 6 kadın; ort. yaş $64.5 \pm 8.7$ yıl; dağılım, 49-85 yıl) çalışmaya alındı. Kırk beş bacak ve 51 hedef damar vardı. İliofemoral veya femoropopliteal baypas greftli olan bu hastalara hibrid işlem yapıldı.

Bulgular: İlk girişimde 48 hedef damara (\%94.1) 55 stent yerleştirildi. Başarısız üç hedef damar (\%5.9), daha sonra cerrahi revaskülarizasyon ile tedavi edildi. İşleme bağlı mortalite görülmedi. Bir hastaya 70 gün sonra diz altı ampütasyon yapıldı. İki hastaya tek parmak ampütasyonu yapıldı. Bir hastada kontrast nefropati gelişti ve bu hasta tıbbi olarak tedavi edildi. Ortalama takip süresi $16.7 \pm 5$ (dağılım, 8-29) ay idi. Takip sonrasında, 41 stent müdahale olmaksızın açık olarak tespit edildi ve primer açıklık oranı \%74.5 idi. Beş stent trombozu hastası (\%12.5) farklı zamanlarda tedavi edildi.

Sonuç: Çalışma sonuçlarımız, ciddi komorbiditeli hastalara perkütan translüminal anjiyoplasti/stent tedavisinin önerilebileceğini göstermektedir. Stent serilerindeki nispeten düşük komplikasyon oranları, deneyimli ellerde perkütan translüminal anjiyoplasti/stentin, cerrahi revaskülarizasyona kıyasla, işleme bağlı riskinin daha düşük olduğuna işaret etmektedir. Hibrid işlem, daha önce girişimde bulunulan komorbiditeli hastalarda bacak kurtarma amacıyla uygun bir işlem olarak görülmektedir.

Anahtar sözcükler: Klodikasyon; hibrid revaskülarizasyon; perkütan translüminal anjiyoplasti/stent; total oklüzyon.

Received: November 14, 2017 Accepted: April 20, 2018

Correspondence: Emin Can Ata, MD. Özel Eskişehir Anadolu Hastanesi, Kalp ve Damar Cerrahisi, 26020 Odunpazarı, Eskişehir, Turkey. Tel: +90 222 - 2214848 e-mail: dr.enata@yahoo.com 
Iliofemoral occlusion is common, particularly in the elderly, and it poses a high-risk of long-term suffering, amputation, and early death. ${ }^{[1]}$ In the great majority of cases, the cause is atherosclerosis. Iliofemoral occlusion in its mild form may be limited to intermittent claudication, pain in the lower extremities which is triggered by exertion relieves during the rest. The ageand gender-standardized incidence rate of combined above-knee and below-knee amputations due to iliofemoral occlusion was 24.1/100,000 person-years during 1998-2002 in the United Kingdom. Thirty-four percent of amputees underwent repetitive amputation and overall mortality was $80 \% .^{[2]}$ This is due to the fact that atherosclerosis can progress for a long time without producing any direct symptoms, the number of individuals who suffer from the disease is unknown. Meanwhile, the risk increases along with the age. ${ }^{[3,4]}$

All medical treatment of iliofemoral occlusion includes aggressively intervening the common risk factors for atherosclerosis, such as, hypertension, high lipid levels, and diabetes mellitus (DM), and correction of smoking habits, physical inactivity and overweight. ${ }^{[4]}$ When it reaches the level of affecting life quality or lifethreatening extend, surgical or endovascular intervention should be performed to relieve ischemic pain and to prevent limb loss or early death. ${ }^{[5,6]}$

Since it is firstly described by Charles Dotters in 1964, endovascular treatment of iliofemoral occlusion has been popularized every other day. ${ }^{[7]}$ Owing to the cumulative data about the superiority of percutaneous transluminal angioplasty (PTA)/stent treatment in selected patients of iliofemoral occlusion compared to another revascularization method, not only are these procedures being done at most of the centers by interventional cardiologists, but also these are performing by radiologists and as well as cardiovascular surgeons at present time. The technical advances in stents and catheter materials are the other important aspects of successful revascularization and long-term patency.

\section{PATIENTS AND METHODS}

The study protocol was approved by the Ethics Committee of Private Eskişehir Anadolu Hospital. A written informed consent was obtained from each patient. The study was conducted in accordance with the principles of the Declaration of Helsinki.

A total of 40 symptomatic patients (34 males, 6 females; mean age $64.5 \pm 8.7$ years; range, 49 to 85 years) were referred to our clinic between January 2015 and March 2017 due to totally occluded iliac or femoral artery disease as confirmed angiographically.
There were 45 legs and 51 targeted vessels. All the iliac lesions were classified according to the TransAtlantic Inter-Society Consensus on the Management of Peripheral Arterial Disease (TASC II) classification before procedure, symptoms such as rest pain, claudication and wound of the foot identified, pedal artery pulses examined and recorded before and after procedure. Comorbid factors were questioned and risks of the procedure were evaluated carefully. Baseline clinical characteristics of these patients and location of occlusion are shown in Table 1.

All the procedures were done in the hybrid theater under scopy, before procedure patients were given $300 \mathrm{mg}$ clopidogrel, during the procedure heparin was given to adjust activated clotting time about 180 to 250 s, previously used antiplatelet and vitamin K antagonist (VKA) medicines did not ceased before procedure. As soon as the procedure finished patients were administered $150 \mathrm{mg}$ aspirin. All the patients were discharged with dual antiplatelet therapy and low-molecular-weight heparin was given for additional 10 days.

The access sites were given local anesthesia, percutaneous or surgical exposure for access was

Table 1. Preoperative patient characteristics

\begin{tabular}{lcc}
\hline & $\mathrm{n}$ & $\%$ \\
\hline Comorbid factors & 11 & 27.5 \\
Hypertension & 8 & 20 \\
Diabetes mellitus & 7 & 17.5 \\
Hypercholesterolemia & 24 & 60 \\
Smoking & 10 & 25 \\
Cardiac operations & 17 & 42.5 \\
Vascular operations & & \\
Indication & 37 & 92.5 \\
Claudication & 3 & 7.5 \\
Rest pain & 6 & 15 \\
Ischemic necrosis & & \\
Location of occlusion & 36 & 70.6 \\
Iliac artery & 15 & 29.4 \\
Femoral artery & 5 & - \\
Coexisting BTK artery & & \\
TASC II classification of IA & 4 & 10 \\
A & 18 & 45 \\
B & 17 & 42.5 \\
C & 1 & 2.5 \\
D
\end{tabular}

BTK: Below-the-knee; IA: Iliac artery; TASC II: Trans-Atlantic InterSociety Consensus on the Management of Peripheral Arterial Disease. 
Table 2. Access sites for percutaneous transluminal angioplasty/stent treatment

\begin{tabular}{lcc}
\hline & $\mathrm{n}$ & $\%$ \\
\hline Percutaneous & & \\
Ipsilateral femoral & 26 & 52 \\
Brachial & 3 & 6 \\
Popliteal & 5 & 10 \\
Brachial + femoral & 1 & 2 \\
Contralateral femoral & 9 & 18 \\
Surgical exposure & & \\
Femoral & 3 & 6 \\
Tibialis posterior & 2 & 4 \\
Dorsalis pedis & 1 & 2 \\
Total & 50 & 100 \\
\hline
\end{tabular}

determined according to the patient status and vascular anatomy. Percutaneous access was done by ultrasound (US) guide for avoiding multiple puncture. Then appropriate size of guidewire and catheter was chosen after $8 \mathrm{~F}$ sheath was placed. We routinely use hydrophilic guidewire (NaviPro, Boston scientific, Boston, USA) and speX ${ }^{\mathrm{TM}}$ shapeable support catheter (Maquet Getinge Group, New Jersey, USA) for cross the common femoral artery (CFA) and iliac artery occlusion. For popliteal and below-the-knee (BTK) artery, we used a Wingman support catheter. All of the access sites are shown in Table 2. Figure 1 shows accessing through dorsalis pedis artery (DPA).

Except two failed patients, 38 patients (95\%) were successfully traversed the occlusion and 55 stents were implanted in 48 target lesions primarily. Balloonexpendable stents were mostly applied for iliac and femoral lesions, and self-expendable stents were preserved for more calcified infrainguinal lesions. Two stented grafts were implanted one iliac and one superficial femoral artery (SFA) due to dissection during balloon inflation. Figure 2 shows SFA dissection during balloon inflation and stent treatment. Implanted stent types are shown in Table 3.

Three of in-stent restenosis patients were treated PTA alone. Six limbs were done additional BTK drugcoated balloon (DCB) besides iliofemoral stents. An angiographic view was taken before the completion of the procedure. The access sheath was kept four more hours before retrieval in case of emergency. Patients without complications were discharged the other day after intervention and called for check-up within one month and, then, every three months. Duplex US was done, if the patient had pulse deficits and claudication of relevant limbs.

\section{Statistical analysis}

Kaplan Meier analysis is used for primary stent patency rates.

\section{RESULTS}

The mean follow-up was $16.7 \pm 5$ (range, 8 to 29) months. There were one mortality $(2.5 \%)$ due to rectum cancer three months after the procedure. Initial attempt PTA failed in two patients (5\%) with TASC II C and D lesions and these patients were successfully treated surgically. A total of 48 of the target vessels $(94.1 \%)$ were treated successfully during the initial intervention. Two patients received medical treatment due to symptomatic stent stenosis due to unsuitable to re-intervention. A total of 41 stents were
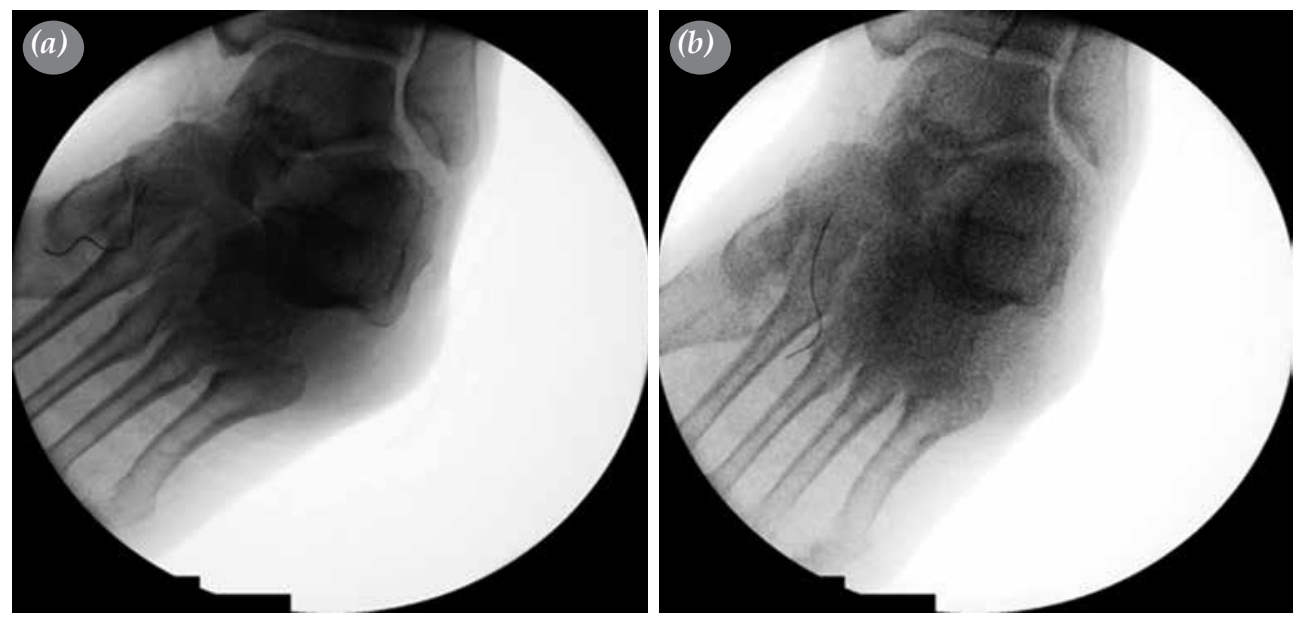

Figure 1. Dorsalis pedis artery chosen for access site. (a) Accessing through dorsalis pedis artery. (b) Introducing guidewire. 

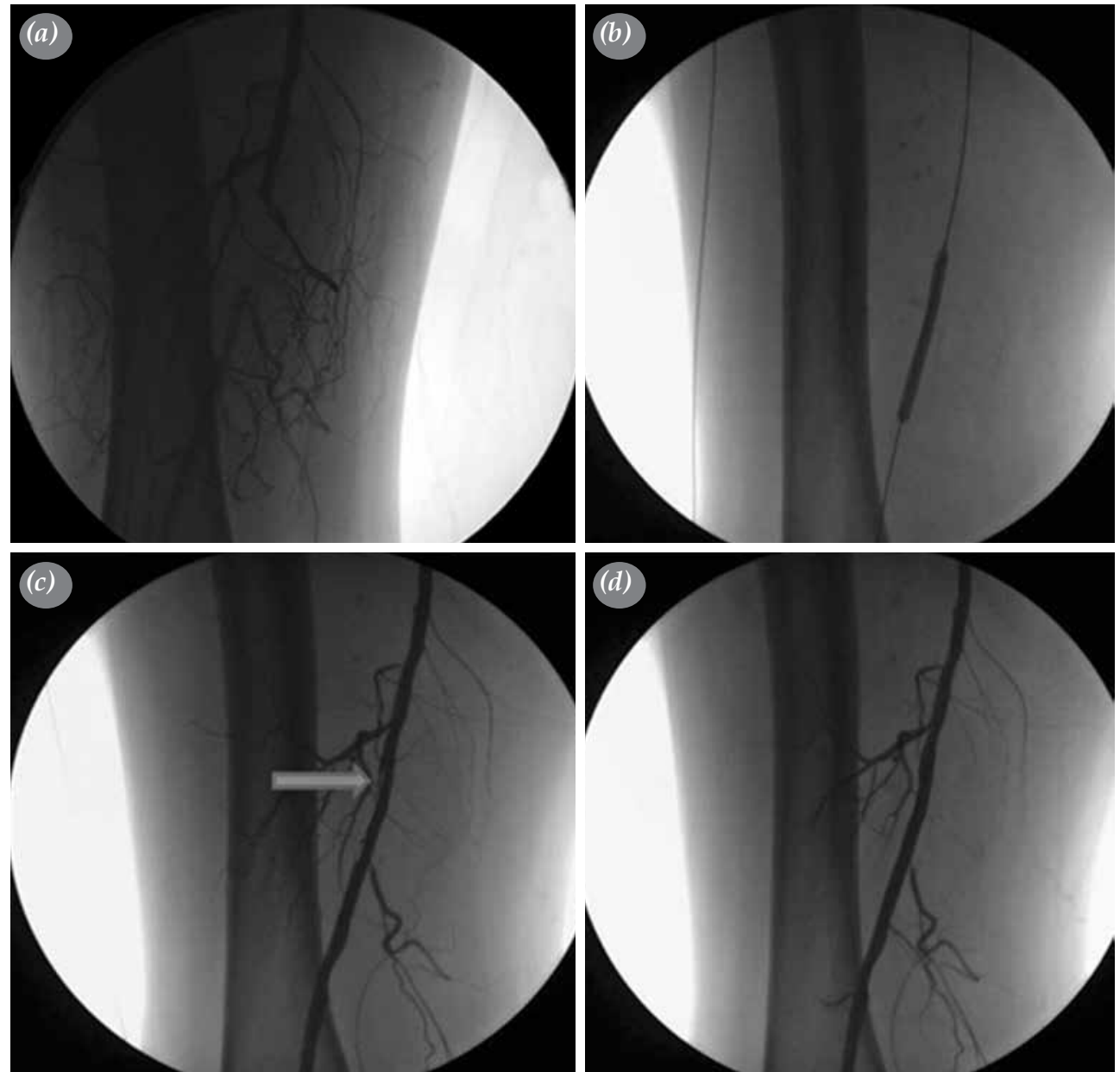

Figure 2. Femoral artery dissection and treatment. (a) Before, (b) balloon inflated, (c) dissection, (d) after stented graft implantation.

found to be patent at the end of a mean follow-up of $16.7 \pm 5$ months without any intervention with a primary patency rate of $74.5 \%$. At six month, one year, and two years, the rate of stent patency was $94.5 \%$, $85.4 \%$, and $74.5 \%$, accordingly. Cumulative primary stent patency rates were shown using the KaplanMeier curve (Figure 3). Some typical angiographic results illustrating recanalization and stenting of totally occluded iliac and femoral artery are shown in Figures 4 and 5.
In 35 patients $(87.5 \%)$, pedal pulses were palpable and relieved from claudication during follow-up. The most common complication was stent thrombosis. There were eight stents (14.5\%) in five patients with stent thrombosis during follow-up. These patients were treated using different methods. Figure 6 shows stent thrombosis and PTA treatment. Time from intervention to stent thrombosis and management is shown in Table 4. Two patients with four stents underwent successful surgical

Table 3. Stent types, numbers and brand names

\begin{tabular}{lccc}
\hline Stent types & $\mathrm{n}$ & $\%$ & Brand names \\
\hline Balloon expandable & 35 & 57.4 & Restorer \\
Self expandable & 18 & 29.5 & Evolution \\
Graft stent & 2 & 3.3 & Fluency \\
Drug-coated balloon & 6 & 9.8 & Luminor-14, iVascular \\
\hline
\end{tabular}




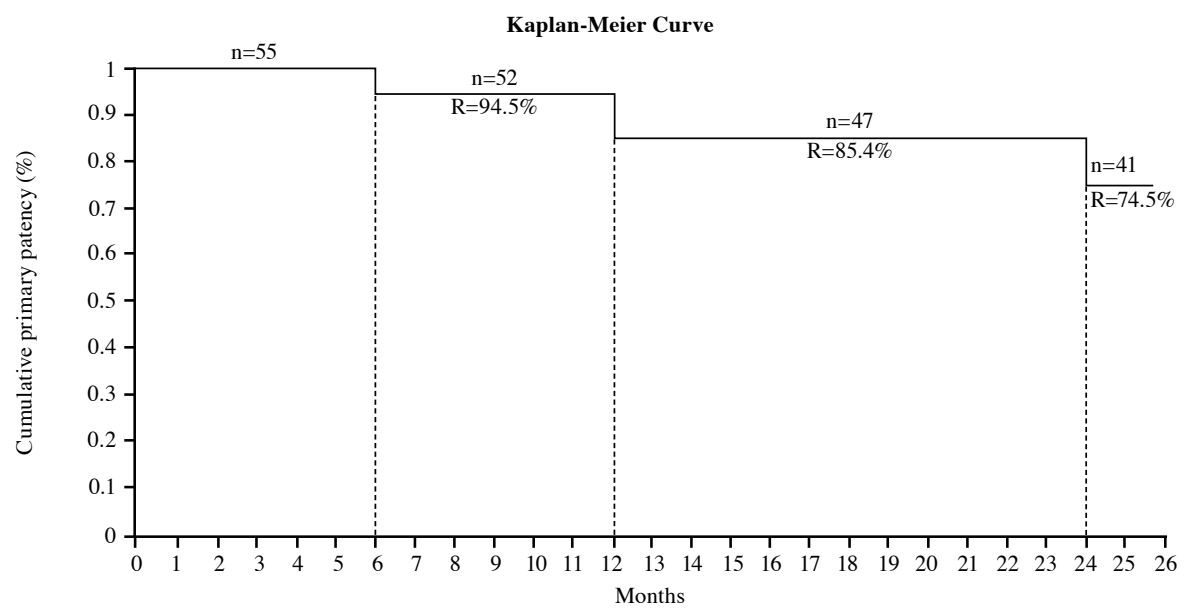

Figure 3. Cumulative primary patency rates of stents.

$\mathrm{N}$ : Number of patients at risk; R: Cumulative primary patency rates.

revascularization after two and 18 months due to stent occlusion.

Below-the-knee amputation occurred in one patient (2.5\%) 70 days after the procedure who previously underwent iliofemoral bypass graft. Two patients (5\%) underwent finger amputation who had finger infections before the endovascular intervention. Limb salvage rate was $93.3 \%$. Cerebral embolism and concomitant contrast nephropathy occurred in one patient $(2.5 \%)$ who stayed for 22 days for medical treatment before discharge. The overall morbidity rate was $30 \%$. The mean length of hospital stay was 1.5 (range, 1 to 22)
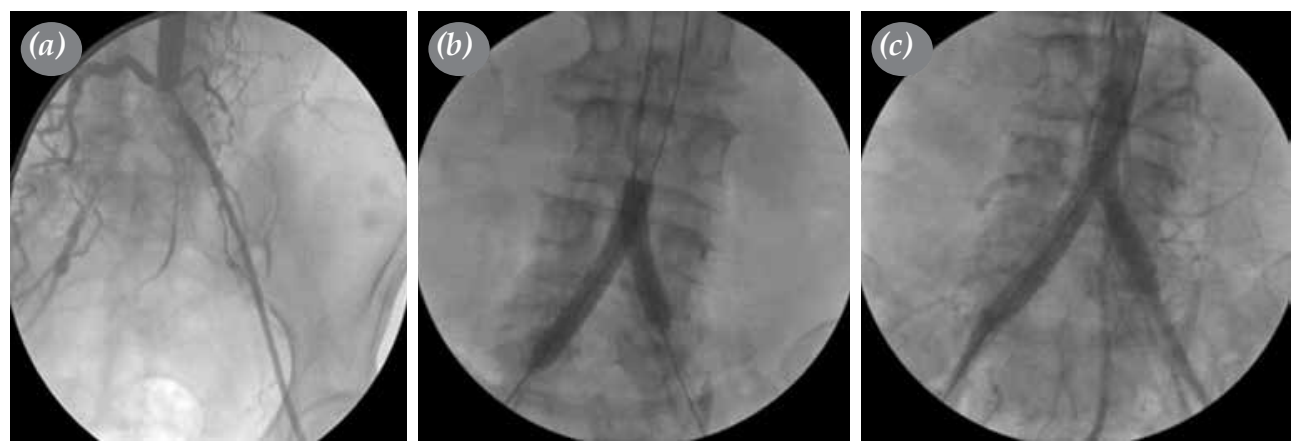

Figure 4. Bilateral iliac artery stenting. (a) Before, (b) balloon inflated, (c) after stent implantation.
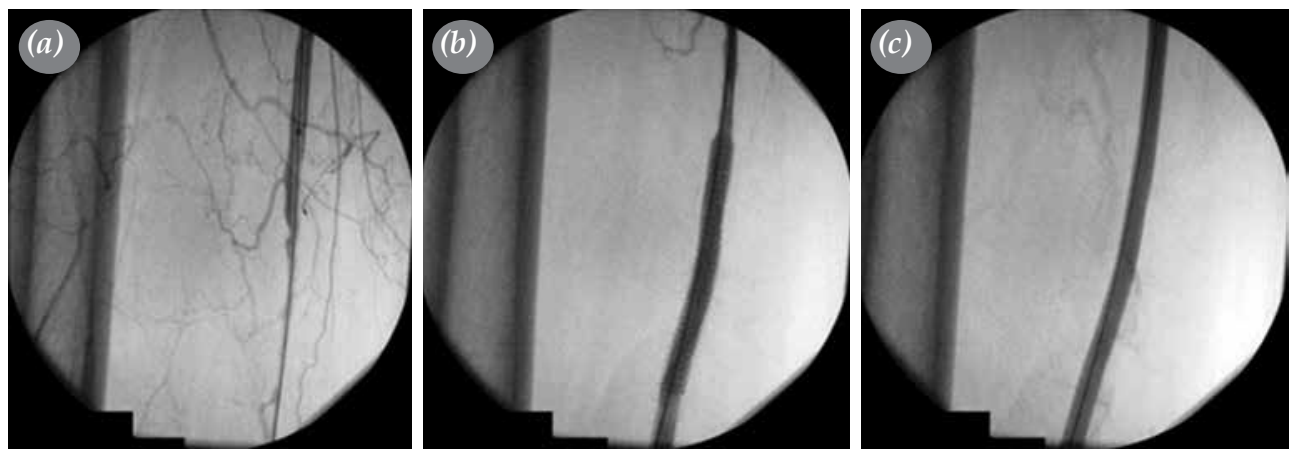

Figure 5. Percutaneous transluminal angioplasty/stent treatment of superficial femoral artery. (a) Before, (b) stent implanted, (c) after additional balloon inflated. 

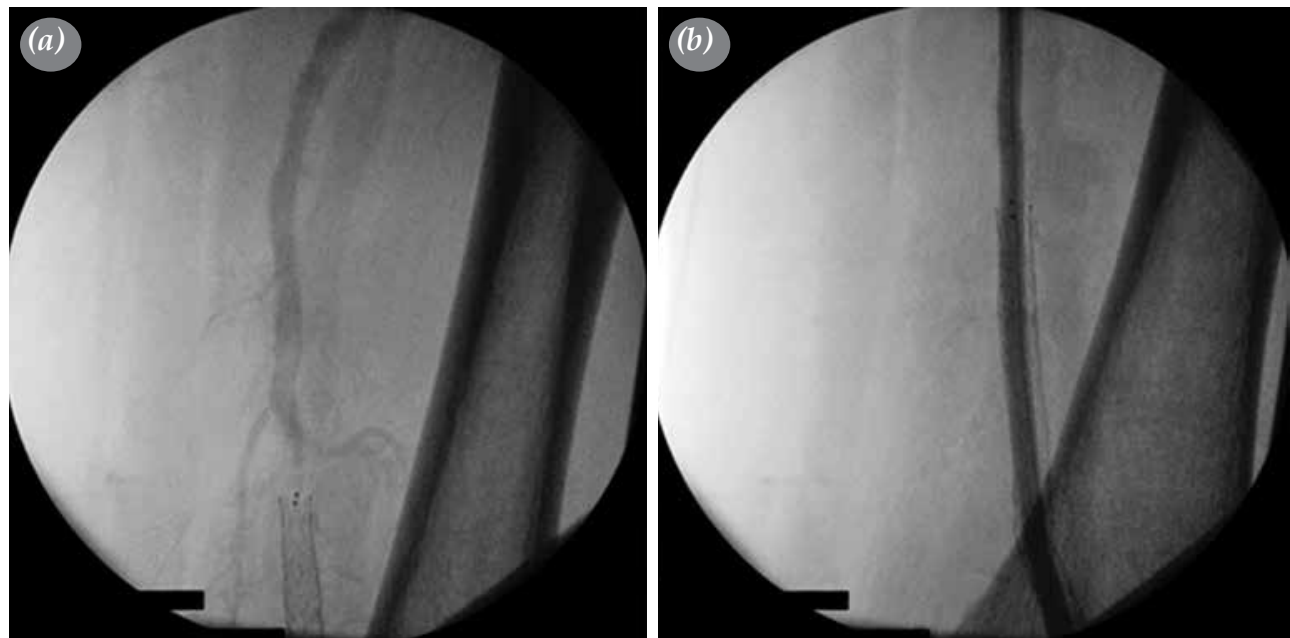

Figure 6. Stent thrombosis treated percutaneous transluminal angioplasty. (a) Stent thrombosis, (b) after percutaneous transluminal angioplasty.

Table 4. Stent thrombosis time intervals and management

\begin{tabular}{lll}
\hline & Time intervals & Management \\
\hline 1 & The same procedure day & Emergency thrombectomy and percutaneous transluminal angioplasty \\
2 & After three months & Thrombectomy and percutaneous transluminal angioplasty \\
3 & After five months & Thrombectomy and percutaneous transluminal angioplasty \\
4 & After 10 months & Percutaneous transluminal angioplasty \\
5 & After 11 months & Percutaneous transluminal angioplasty \\
\hline
\end{tabular}

Table 5. Complications and management

\begin{tabular}{lccc}
\hline Complications & $\mathrm{n}$ & $\%$ & Treatment \\
\hline Dissection & & & \\
$\quad$ Common iliac & 1 & 2.5 & Stented graft implantation \\
$\quad$ Superficial femoral artery & 1 & 2.5 & Stented graft implantation \\
Stent thrombosis & 5 & 12.5 & Embolectomy or PTA \\
Access site thrombosis & 1 & 2.5 & Emergency embolectomy \\
Contrast nephropathy + cerebrovascular event & 1 & 2.5 & Medical treatment \\
Amputation & & & - \\
$\quad$ Below-knee & 1 & 2.5 & - \\
$\quad$ Finger & 2 & 5 & Surgical revascularization \\
Failed access & 2 & 5 & \\
Overall morbidity & 12 & 30 & \\
Overall mortality & 1 & 2.5 & \\
\hline
\end{tabular}

PTA: Percutaneous transluminal angioplasty. 
days. There was no procedure-related mortality. All complications are shown in Table 5.

\section{DISCUSSION}

Prior to PTA/stent techniques came into use, open surgical revascularization for the iliofemoral occlusive disease was an opt for aortofemoral or femoropopliteal bypass as the favored procedures thanks to relatively low morbidity and mortality rates in selected patients. Despite this, surgical procedures are still associated with significant mortality and morbidity in highrisk comorbid patients. ${ }^{[8]}$ Due to its less invasive nature, shorter hospital stay, and lower infection rates, PTA/stent treatment has become an alternative to surgical intervention among comorbid patients. In particular, several studies have reported initial success and patency rates with PTA/stent similar to surgery stirred inclination to PTA/stent. ${ }^{[9-11]}$

The treatment of total occlusions, thought to be a limitation of percutaneous treatment due to more technically adversity than subtotal occlusion, is currently possible owing to the advancement of catheter, stent, and DCBs. Due to facilitating access to the most tortuous anatomy, various levels of tip stiffness provide excellent visibility. We routinely use hydrophilic guidewires and SpeX shapeable support catheters to drill totally-occluded vessels. In a previous study, we also experienced an $8 \mathrm{~F}$ long sheath and provided closer to the level of the occlusion and increased the success of the procedure. ${ }^{[12]}$

We did not give preference to any specific stent, a single stent was preferred to cover the entire lesion, and multiple stents were used, if necessary. In all cases, bare metal self-expanding or balloon-expanding nitinol stents were applied. It has been reported that long-term patency of SFA intervention comparing endografts and bare metal stents were similar. ${ }^{[10,13]}$ Compared to uncoated balloons or drug-eluting stents, the treatment of infrapopliteal arteries with DCBs is associated with similar clinical outcomes and favorable angiographic efficacy at one-year follow-up. ${ }^{[14]}$ In our series, we performed five patients DCB additionally to iliofemoral stenting, all patients had the significant ischemic finger or heel involvement.

Some shreds of evidence showed that shorter lesions do well with PTA/stent, while longer lesions have significantly lower patency rates. ${ }^{[15]}$ The TASC II recommendations include an endovascular approach for shorter lesions and a bypass for longer lesions. ${ }^{[16]}$ We mostly followed this principle in our practice. In our patient series, we successfully stented one class D lesion, but failed to cross one class B and one class $\mathrm{C}$ lesion, and they were treated through surgical revascularization.

Hybrid revascularization has been also increasingly implemented for multilevel revascularization when more complicated lesions are encountered to handle. In the elderly and in patients with significant comorbidities, a hybrid procedure may be more advisable, as the patency rates are comparable with open or endovascular revascularization and reduce early mortality and morbidity. ${ }^{[17,18]}$ Eight limbs (17.8\%) of five patients who previously underwent bypass graft surgery were the most challenging patients in our series. We performed the hybrid procedure, as neither redo operation nor the endovascular treatment alone was appropriate to these patients. Surgical exposure of graft was done first, and thrombectomy was performed for the proximal flow and, then, both stenotic anastomotic sites were stented successfully.

We believe the US guide puncture is very useful for all endovascular practitioners. Deep located and the pulseless vessel cannot be cannulated easily, and routine use prevents us from multiple punctures, which may lead to readmission due to pseudoaneurysm formation, puncture site hematoma, arteriovenous fistula, fistula and wound infection. ${ }^{[19]}$

Notwithstanding the technical advances and maximum medical therapy, in-stent restenosis and occlusion is the most frequent complication and major causes of amputation, if left untreated immediately. ${ }^{[20,21]}$ In addition to lesion-specific factors, such as longer length and smaller vessel diameter, patient characteristics including diabetes mellitus, can increase the risk of restenosis. ${ }^{[22]}$ In our series, we found eight stents (14.5\%) of five patients had stent occlusion at different times. All were treated at once and prevented from limb loss. However, we were unable to treat four stents restenosis of two patients, as the lesion extends outside the stents. Smoking would be the major contributor to this kind of evitable complication. Commercially available drug-eluting stents may give hope in future; however, its common use is limited because of current cost-effective perspective. ${ }^{[23,24]}$

Due to the complexity and diversity of the patients in our series, it was impossible to make up a control group for a randomized study. That was the limitation of this study. Lack of cost-effective analysis and long-term results are other limited aspects of this study. Therefore, further large-scale and long-term studies are needed.

In conclusion, percutaneous transluminal angioplasty/stent therapy is an effective revascularization option in appropriately selected patients with the peripheral occlusive disease 
presenting with debilitating claudication or critical limb ischemia. Once indicated, this therapy is initiated by identifying the target occlusion angiographically. Occluded lesion must be traversed using a combination of appropriate guide wire and catheter. If done by an experienced and collaborated team in the hybrid operating theater, even a complicated procedure can be successfully performed.

\section{Acknowledgements}

We thank all the physicians who confidently referred patients to our clinic for endovascular and hybrid revascularization. In addition, we thank Barbaros Dokumac1, MD for his careful review and comment. We also thank Aynur Gunduz for her enormous assistance of data collection and manuscript design.

\section{Declaration of conflicting interests}

The authors declared no conflicts of interest with respect to the authorship and/or publication of this article.

\section{Funding}

The authors received no financial support for the research and/or authorship of this article.

\section{REFERENCES}

1. Cea Soriano L, Fowkes FGR, Johansson S, Allum AM, García Rodriguez LA. Cardiovascular outcomes for patients with symptomatic peripheral artery disease: A cohort study in The Health Improvement Network (THIN) in the UK. Eur J Prev Cardiol 2017;24:1927-37.

2. Remes L, Isoaho R, Vahlberg T, Hiekkanen H, Korhonen $\mathrm{K}$, Viitanen $\mathrm{M}$, et al. Major lower extremity amputation in elderly patients with peripheral arterial disease: incidence and survival rates. Aging Clin Exp Res 2008;20:385-93.

3. Watson K, Watson BD, Pater KS. Peripheral arterial disease: a review of disease awareness and management. Am J Geriatr Pharmacother 2006;4:365-79.

4. Conen D, Everett BM, Kurth T, Creager MA, Buring JE, Ridker PM, et al. Smoking, smoking cessation, [corrected] and risk for symptomatic peripheral artery disease in women: a cohort study. Ann Intern Med 2011;154:719-26.

5. Ricco JB, Thanh Phong L, Belmonte R, Schneider F, Valagier A, Illuminati $\mathrm{G}$, et al. Open surgery for chronic limb ischemia: a review. J Cardiovasc Surg (Torino) 2013;54:719-27.

6. Dattilo PB, Casserly IP. Critical limb ischemia: endovascular strategies for limb salvage. Prog Cardiovasc Dis 2011;54:47-60.

7. Dotter CT, Judkins MP. Transluminal treatment of arteriosclerotic obstruction. description of a new technic and a preliminary report of its application. Circulation 1964;30:654-70.

8. Siracuse JJ, Menard MT, Eslami MH, Kalish JA, Robinson WP, Eberhardt RT, et al. Comparison of open and endovascular treatment of patients with critical limb ischemia in the Vascular Quality Initiative. J Vasc Surg 2016;63:958-65.

9. Janczak D, Malinowski M, Bakowski W, Krakowska K, Marschollek K, Marschollek P, et al. Comparison of the Incidence of Complications and Secondary Surgical Interventions Necessary in Patients with Chronic Lower Limb Ischemia Treated by Both Open and Endovascular Surgeries.
Ann Thorac Cardiovasc Surg 2017;23:135-40.

10. Islam J, Robbs JV. Comparison between superficial femoral artery stenting and bypass surgery in severe lower-limb ischaemia: a retrospective study. Cardiovasc J Afr 2015;26:34-7.

11. Fu X, Zhang Z, Liang K, Shi S, Wang G, Zhang K, et al. Angioplasty versus bypass surgery in patients with critical limb ischemia-a meta-analysis. Int J Clin Exp Med 2015;8:10595-602.

12. Cannavale A, Ali T, Shen CY, Kassimis G, Krokidis M. Recanalization of peripheral chronic total occlusions: 'no fancy devices, just a crossing catheter'. Expert Rev Cardiovasc Ther 2017;15:221-5.

13. Geraghty PJ, Mewissen MW, Jaff MR, Ansel GM. Three-year results of the VIBRANT trial of VIABAHN endoprosthesis versus bare nitinol stent implantation for complex superficial femoral artery occlusive disease. J Vasc Surg 2013;58:386-95.

14. Cassese S, Ndrepepa G, Liistro F, Fanelli F, Kufner S, Ott I, et al. Drug-Coated Balloons for Revascularization of Infrapopliteal Arteries: A Meta-Analysis of Randomized Trials. JACC Cardiovasc Interv 2016;9:1072-80.

15. Malas MB, Enwerem N, Qazi U, Brown B, Schneider EB, Reifsnyder $\mathrm{T}$, et al. Comparison of surgical bypass with angioplasty and stenting of superficial femoral artery disease. J Vasc Surg 2014;59:129-35.

16. Norgren L, Hiatt WR, Dormandy JA, Nehler MR, Harris KA, Fowkes FG. Inter-Society Consensus for the Management of Peripheral Arterial Disease (TASC II). J Vasc Surg 2007;45 Suppl S:S5-67.

17. Dosluoglu HH, Lall P, Cherr GS, Harris LM, Dryjski ML. Role of simple and complex hybrid revascularization procedures for symptomatic lower extremity occlusive disease. J Vasc Surg 2010;51:1425-35.

18. Uğur M, Alp İ, Arslan G, Şenay Ş, Selçuk İ, Selçuk A, et al. Vasküler hastalıkların yönetiminde endovasküler ve hibrid uygulamalar: Kardiyovasküler cerrahi kliniği deneyimleri. Türk Göğüs Kalp Dama 2012;20:230-42.

19. Seto AH, Abu-Fadel MS, Sparling JM, Zacharias SJ, Daly TS, Harrison AT, et al. Real-time ultrasound guidance facilitates femoral arterial access and reduces vascular complications: FAUST (Femoral Arterial Access With Ultrasound Trial). JACC Cardiovasc Interv 2010;3:751-8.

20. Gray BH, Buchan JA. The treatment of superficial femoral artery in-stent restenosis: The jury is still out. JACC Cardiovasc Interv 2016;9:1393-6.

21. Singh S, Armstrong EJ, Laird JR. Understanding iliac and femoropopliteal artery restenosis. Endovascular Today 2013:36-40.

22. Mehran R, Dangas G, Abizaid AS, Mintz GS, Lansky AJ, Satler LF, et al. Angiographic patterns of in-stent restenosis: classification and implications for long-term outcome. Circulation 1999;100:1872-8.

23. Hooker JB, Hawkins BM. Critical limb ischemia update and the evolving role of drug-elution technologies. Expert Rev Cardiovasc Ther 2017;15:891-6.

24. Kayssi A, Al-Atassi T, Oreopoulos G, Roche-Nagle G, Tan KT, Rajan DK. Drug-eluting balloon angioplasty versus uncoated balloon angioplasty for peripheral arterial disease of the lower limbs. Cochrane Database Syst Rev 2016;8:CD011319. 